\title{
Non-small-cell lung cancer in a French department, (1982-1997): management and outcome
}

\author{
J Foeglé', G Hédelin', MP Lebitasy', A Purohit ${ }^{2}$, M Velten' and E Quoix ${ }^{*, 2}$ \\ 'Laboratoire d'épidémiologie et de santé publique, Université Louis Pasteur, Strasbourg, France; ${ }^{2}$ Service de Pneumologie Lyautey, Hôpitaux Universitaires, \\ I, Place de l'Hôpital, 6709I Strasbourg, Cedex, France
}

\begin{abstract}
Addition of chemotherapy to the treatment of non-small-cell lung cancer (NSCLC) resulted in a modest but clear improvement in the survival of selected patients. To ascertain if this translates to improved survival in the whole population of patients, we conducted a retrospective population-based study of a sample of 1738 patients diagnosed with primary NSCLC in a French department between 1982 and 1997. The proportion of women, metastatic cases and adenocarcinoma changed significantly over time, as did their management: use of chemotherapy alone increased from 9.7 to $28.1 \%(P<0.000 \mathrm{I})$, while the use of radiotherapy alone decreased from 32.2 to $9.4 \%(P<0.0001)$. The 5 -year survival probability was $15.7 \%$ for all patients and $32.6 \%$ for those with resectable disease. The I- and 2-year survival probabilities were 38.2 and I5.6\% in locally advanced disease, and were, respectively, 16.8 and $5.2 \%$ in metastatic disease. Disease extent and histological subtype were significant independent prognostic factors. Survival of resectable disease was longer among patients treated with surgery or surgery plus chemotherapy, while better outcomes for locally advanced disease were associated with radiation plus chemotherapy. In metastastic disease, patients treated by classical agent without platin or palliative care only had the shortest survival. Despite changes in treatment in accordance with the state-of-the-art, overall survival did not improve over time. It is not unlikely that more patients with bad PS were diagnosed during the latter end of the study period. This could at least partially explain the absence of detection of an overall improvement in survival.
\end{abstract}

British Journal of Cancer (2005) 92, 459-466. doi: I 0.1038/sj.bjc.6602342 www.bjcancer.com

Published online 25 January 2005

(c) 2005 Cancer Research UK

Keywords: non-small-cell lung cancer; management; survival; surgery; radiotherapy; chemotherapy

Lung cancer, one of the most common malignancies, is the leading cause of cancer death among men through out the industrialised world (Ferlay et al, 2001). Since 1987, lung cancer has caused more deaths than breast cancer among North American women (US Public Health Service, 2001), and it is now the third leading cause of cancer deaths among French women (Hill and Doyon, 2004).

Non-small-cell lung cancer accounts for approximately $75 \%$ of all lung cancers. Its prognosis is poor: 5-year survival rates range from $60 \%$ in resected stage IA disease to $5 \%$ in stage IIIB and $1 \%$ in stage IV (Mountain, 1997). At diagnosis, approximately $75 \%$ of patients have tumours classified as stage III or IV disease (Fry et al, 1999).

Management of Non-small-cell lung cancer (NSCLC) has changed substantially over the past two decades with an increasing use of chemotherapy. At the beginning of the 1980s, the standard treatments were surgery for resectable tumours, mediastinal irradiation for locally advanced disease and supportive care for metastatic disease. Meta-analyses (Souquet et al, 1993; NSCLCCG, 1995) of the clinical trials comparing chemotherapy $v s$ no chemotherapy report modest but clear improvement in survival for patients with metastatic or locally advanced disease who are treated with cisplatin-based chemotherapy and a trend towards improved survival with adjuvant chemotherapy in resectable

\footnotetext{
*Correspondence: Dr E Quoix;

E-mail: elisabeth.quoix@chru-strasbourg.fr

Received 3 September 2004; revised 25 November 2004; accepted 25 November 2004; published online 25 January 2005
}

disease. (The favourable impact of adjuvant chemotherapy has just been demonstrated very recently; The IALT Collaborative Group, 2004). Preoperative chemotherapy strategies might improve survival in resectable stage IIIA disease (Roth et al, 1994) as well as in stages I and II (Depierre et al, 2002).

To evaluate the effect on survival of these management changes in a population-based study, we conducted a retrospective study over a 16-year period of a sample of 1738 patients diagnosed with NSCLC in the department of Bas-Rhin (northeastern France).

\section{PATIENTS AND METHODS}

\section{Patients}

The Bas-Rhin population-based cancer registry furnished us with a list of patients with confirmed NSCLC. This department had a population of roughly 1000000 inhabitants during the study period (INSEE, 1982, 1990, 1999). We included $40 \%$ of the 5071 cases diagnosed between 1982 and 1997 and randomly selected 2028 patients, stratified by year of diagnosis.

We reviewed the medical records of each patient and excluded those with in situ carcinoma or a combination of small-cell and NSCLC. The following data were collected: age, sex, date of diagnosis, histological subtype, investigations performed for diagnostic and staging purposes and disease extent. We did not attempt to assign stages retrospectively but used the stage assigned by the patient's physician at diagnosis: resectable disease, locally 
advanced unresectable disease and metastatic disease. The stage was classified as undetermined if the chart did not report the local extent of the disease at diagnosis and if no metastatic site was detected.

Initial treatment (surgery, radiotherapy, chemotherapy, palliative care) and any clinical trial participation were also recorded. Chemotherapy was divided into classical agents and more recent agents (vinorelbine, gemcitabine, irinotecan) and subdivided into protocol with or without platin.

Survival was estimated from the date of pathological diagnosis. The end of follow-up was 31 December 2002.

\section{Statistical methods}

Descriptive analysis We defined four consecutive periods covering 4 years each. Differences between proportions were assessed with either Pearson's $\chi^{2}$ test or Fisher's exact test. Differences between the means of continuous variables were evaluated with Student's $t$-test or, if the comparison involved more than two groups, one-way analysis of variance. The 8.2 SAS software package (SAS Institute, Cary, NC, USA) was used to analyse the data.

Survival analysis Our study covered 16 years. To eliminate the effect of improved survival for the other pathologies and the effect of age-related mortality, we conducted simple and multiple regressive analysis of relative rather than crude survival (Estève et al, 1990) with the RELSURV software package (Hédelin, 2003). The variables with a $P$-value of 0.20 or less in the simple regressive analysis were entered in the multiple regressive analysis. Sex and period were forced in the model. The proportionality assumption has been verified using interaction with time. Interactions between variables were tested, and none was statistically significant.

Power considerations Our principal objective was to determine whether relative survival globally changed in NSCLC patients between 1982 and 1997. Using registry data, we estimated that the 5 -year relative survival rate was $15 \%$ in the early 1980 s, and we wanted to be able to detect an increase of at least five points, that is, a 5-year relative survival rate of $20 \%$ at the end of the 1990 s under the assumption of the proportionality of the risks. With the formula given in Jung and Hui (2002) and assuming a one-sided test with an alpha level of 0.05 and a power of 0.80 , we estimated that a sample size of 490 patients would be required in each of the four periods.

\section{RESULTS}

\section{Descriptive analysis}

We excluded 290 of the 2028 patients randomly selected from the registry: 197 patients had missing medical records, and 93 did not meet the inclusion criteria. The study thus included 1738 patients, $89.8 \%$ of the 1935 eligible.

The 197 eligible patients excluded from the study differed in some ways from the 1738 patients included. The proportion of women in these groups was 17.2 and 9.2\%, respectively $(P=0.0001)$, the median age 69.0 and 63.0 years $(P<0.0001)$, and their median survival time (MST) substantially different (21.6 vs 45.3 weeks, $P=0.00006$ ). The proportion of cases with missing data decreased significantly over the study period from 15.5 to 9.5\% $(P=0.0109)$. Table 1 summarises the patients' characteristics and their trends over time.

The proportion of metastatic disease increased over the study period, and the histological distribution changed, especially in the last period, adenocarcinoma became more frequent and squamous cell carcinoma less so (Table 1).

Table 2 reports the diagnostic and staging procedures performed according to the period.

On 31 December 2002, 5.9\% of the patients were still alive, $92.8 \%$ had died and $1.3 \%$ had been lost to follow-up.

Table I Characteristics of the study sample

\begin{tabular}{|c|c|c|c|c|c|c|c|c|c|}
\hline \multirow[b]{2}{*}{ Period } & \multicolumn{2}{|c|}{$1982-85$} & \multicolumn{2}{|c|}{$1986-89$} & \multicolumn{2}{|c|}{$1990-93$} & \multicolumn{2}{|c|}{$1994-97$} & \multirow[b]{2}{*}{$P$} \\
\hline & No. & $\%$ & No. & $\%$ & No. & $\%$ & No. & $\%$ & \\
\hline $\operatorname{Sex} x^{a}$ & & & & & & & & & 0.2044 \\
\hline Male & 319 & 91.4 & 380 & 89.4 & 411 & 87.6 & 431 & 87.1 & \\
\hline Female & 30 & 8.6 & 45 & 10.6 & 58 & 12.4 & 64 & 12.9 & \\
\hline Age (years) & & & & & & & & & 0.0018 \\
\hline$\leqslant 55$ & 82 & 23.5 & 101 & 23.8 & 93 & 19.8 & 108 & 21.8 & \\
\hline $56-70$ & 144 & 41.3 & 210 & 49.4 & 255 & 54.4 & 268 & 54.1 & \\
\hline$>70$ & 123 & 35.2 & 114 & 26.8 & 121 & 25.8 & 119 & 24.0 & \\
\hline Treatment on protocol $^{\mathrm{a}}$ & | | & 3.2 & 6 & 1.4 & 20 & 4.3 & 36 & 7.3 & 0.0001 \\
\hline Disease extent & & & & & & & & & 0.0267 \\
\hline Resectable & 182 & 52.1 & 197 & 46.4 & 204 & 43.5 & 202 & 40.8 & \\
\hline Locally advanced & 52 & 14.9 & 70 & 16.5 & 96 & 20.5 & 94 & 19.0 & \\
\hline Bilateral & 7 & 2.0 & 13 & 3.1 & 6 & 1.3 & 12 & 2.4 & \\
\hline Metastastic & 92 & 26.4 & 126 & 29.6 & 149 & 31.8 & 174 & 35.2 & \\
\hline Undetermined & 16 & 4.6 & 19 & 4.5 & 14 & 3.0 & 13 & 2.6 & \\
\hline Histology & & & & & & & & & 0.0003 \\
\hline Squamous-cell & 229 & 65.6 & 282 & 66.4 & 300 & 64.0 & 267 & 53.9 & \\
\hline Adenocarcinoma & 69 & 19.8 & 92 & 21.6 & 100 & 21.3 & 148 & 29.9 & \\
\hline Bronchioloalveolar & 13 & 3.7 & 16 & 3.8 & 26 & 5.5 & 18 & 3.6 & \\
\hline Large-cell & 35 & 10.0 & 34 & 8.0 & 41 & 8.7 & 51 & 10.3 & \\
\hline Mixed & 3 & 0.9 & I & 0.2 & 2 & 0.4 & $\mid 1$ & 2.2 & \\
\hline
\end{tabular}

aLinear trend significant. 
Table 2 Imaging procedures performed during the study period

\begin{tabular}{|c|c|c|c|c|c|c|c|c|c|}
\hline \multirow[b]{2}{*}{ Period } & \multicolumn{2}{|c|}{$1982-85$} & \multicolumn{2}{|c|}{$1986-89$} & \multicolumn{2}{|c|}{$1990-93$} & \multicolumn{2}{|c|}{$1994-97$} & \multirow[b]{2}{*}{$P$} \\
\hline & No. & $\%$ & No. & $\%$ & No. & $\%$ & No. & $\%$ & \\
\hline Fibrescopy & 336 & 96.6 & 412 & 97.4 & 454 & 97.8 & 474 & 96.3 & 0.4999 \\
\hline Thoracic-CT $\operatorname{scan}^{a}$ & 72 & 20.7 & 177 & 42.0 & 402 & 86.8 & 472 & 96.3 & $<0.0001$ \\
\hline Thoracic NMR ${ }^{b}$ & & & 10 & 2.4 & 12 & 2.6 & | | & 2.3 & 0.9501 \\
\hline Abdominal US & 321 & 92.8 & 376 & 90.4 & 425 & 92.6 & 425 & 89.3 & 0.1973 \\
\hline Adrenal CT scan $^{\mathrm{a}}$ & 18 & 5.2 & 83 & 20.0 & 220 & 48.1 & 245 & 51.6 & $<0.0001$ \\
\hline Abdominal CT $\operatorname{scan}^{\mathrm{a}}$ & 12 & 3.5 & 30 & 7.2 & 82 & 17.9 & 134 & 28.1 & $<0.0001$ \\
\hline Brain $\mathrm{CT}^{\mathrm{a}}$ & 33 & 9.6 & 160 & 38.5 & 313 & 67.7 & 386 & 80.9 & $<0.0001$ \\
\hline Bone scan ${ }^{a}$ & $17 \mid$ & 49.4 & 175 & 42.1 & 212 & 46.4 & 275 & 57.8 & $<0.0001$ \\
\hline Brain scan ${ }^{a}$ & 67 & 19.4 & 16 & 3.9 & 0 & 0.0 & 0 & 0.0 & $<0.0001$ \\
\hline Brain NMR ${ }^{\mathrm{a}}$ & । & 0.3 & 3 & 0.7 & 7 & 1.5 & 10 & 2.1 & 0.0823 \\
\hline Mediastinoscopy & 2 & 0.6 & 4 & 1.0 & 6 & 1.3 & 5 & 1.0 & 0.8181 \\
\hline Other & 35 & 10.1 & 34 & 8.2 & 41 & 9.0 & 37 & 7.8 & 0.6643 \\
\hline
\end{tabular}

a Linear trend significant. ${ }^{b} \chi 2$ calculated from 1986. CT: computed tomography; US: ultrasound; NMR: nuclear magnetic resonance imaging.

Table 3 Therapeutic management over time

\begin{tabular}{|c|c|c|c|c|c|c|c|c|c|}
\hline \multirow[b]{2}{*}{ Period } & \multicolumn{2}{|c|}{ 1982-85 } & \multicolumn{2}{|c|}{$1986-89$} & \multicolumn{2}{|c|}{$1990-93$} & \multicolumn{2}{|c|}{$1994-97$} & \multirow[b]{2}{*}{$P$} \\
\hline & No. & $\%$ & No. & $\%$ & No. & $\%$ & No. & $\%$ & \\
\hline \multicolumn{10}{|l|}{ Resectable disease } \\
\hline Radiotherapy ${ }^{\mathrm{a}}$ & 44 & 24.4 & 35 & 17.9 & 26 & 12.7 & 23 & 11.4 & 0.0023 \\
\hline Surgery ${ }^{a}$ & 60 & 33.3 & 99 & 50.5 & 108 & 52.9 & 112 & 55.4 & $<0.0001$ \\
\hline Chemotherapy & 2 & 1.1 & 2 & 1.0 & 5 & 2.5 & 6 & 3.0 & 0.4290 \\
\hline Surgery+radiotherapy & 31 & 17.2 & 41 & 20.9 & 34 & 16.7 & 24 & 11.9 & 0.1149 \\
\hline Surgery+chemotherapy & $1 \mid$ & 6.1 & 5 & 2.6 & 6 & 2.9 & 8 & 4.0 & 0.2777 \\
\hline Chemotherapy+radiotherapy & 13 & 7.2 & I & 0.5 & 2 & 1.0 & 8 & 4.0 & 0.0004 \\
\hline Surgery+radio+chemotherapy & 8 & 4.4 & 3 & 1.5 & $1 \mid$ & 5.4 & 10 & 5.0 & 0.2043 \\
\hline Supportive care & 11 & 6.1 & 10 & 5.1 & 12 & 5.9 & 11 & 5.4 & 0.9745 \\
\hline \multicolumn{10}{|l|}{ Locally advanced disease } \\
\hline Radiotherapy ${ }^{\mathrm{a}}$ & 28 & 53.8 & 49 & 70.0 & 39 & 40.6 & 12 & 12.9 & $<0.0001$ \\
\hline Chemotherapy & 7 & 13.5 & 3 & 4.3 & 12 & 12.5 & | | & 11.8 & 0.2720 \\
\hline Chemotherapy+surgery & 0 & 0.0 & 0 & 0.0 & 0 & 0.0 & 2 & 2.2 & 0.2419 \\
\hline Chemo+radiotherapy ${ }^{\mathrm{a}}$ & $\mid 1$ & 21.2 & 9 & 12.9 & 29 & 30.2 & 55 & 59.1 & $<0.0001$ \\
\hline Chemo+surgery+radiotherapy & 0 & 0.0 & 3 & 4.3 & 6 & 6.3 & 4 & 4.3 & 0.3247 \\
\hline Supportive care & 6 & 11.5 & 6 & 8.6 & 10 & 10.4 & 9 & 9.7 & 0.9552 \\
\hline \multicolumn{10}{|l|}{ Metastatic disease } \\
\hline Radiotherapy ${ }^{a}$ & 28 & 31.1 & 30 & 24.6 & 17 & 11.5 & 8 & 4.6 & $<0.0001$ \\
\hline Chemotherapy ${ }^{\mathrm{a}}$ & 24 & 26.7 & 32 & 26.2 & 64 & 43.2 & 113 & 65.3 & $<0.0001$ \\
\hline Chemotherapy+surgery & 0 & 0.0 & । & 0.8 & I & 0.7 & 2 & 1.2 & 0.9155 \\
\hline Chemo+radiotherapy ${ }^{\mathrm{a}}$ & 17 & 18.9 & 4 & 3.3 & 15 & 10.1 & 10 & 5.8 & 0.0003 \\
\hline Surgery & 0 & 0.0 & 0 & 0.0 & I & 0.7 & 0 & 0.0 & 0.6754 \\
\hline Chemo+radiotherapy+surgery & 0 & 0.0 & 0 & 0.0 & 0 & 0.0 & l & 0.6 & 0.9999 \\
\hline Supportive care & 21 & 23.3 & 55 & 45.1 & 50 & 33.8 & 39 & 22.5 & 0.0002 \\
\hline
\end{tabular}

ainear trend significant

From period 1 through period 4 , the mean number of metastatic sites detected increased from 0.36 to $0.57(P=0.0057)$ and the mean number of extra-thoracic imaging procedures from 1.79 to $2.87(P<0.0001)$. These increases were significantly correlated $(r=0.13, P<0.0001)$.

In all, 17 cases discovered incidentally at autopsy or who died before diagnosis were excluded from the following analyses.

Treatments for each stage differed significantly from the first to the last study period $(P<0.0001$, Table 3$)$. Data for cases involving bilateral disease and undetermined stage are not shown. The percentage of patients treated with mediastinal irradiation alone decreased over time from 32.2 to $9.4 \%(P<0.0001)$ for every stage. On the other hand, the combined use of chemo- and radiotherapy increased significantly over time for the locally advanced stage and the use of chemotherapy alone increased significantly from 9.7 to $28.1 \%(P<0.0001)$, especially for metastatic disease. The use of surgery alone for resectable disease increased over the study period, while the use of surgery plus radiotherapy did not change. Of the patients in this group, $73.0 \%$ had tumours resected: $64.1 \%$ with pTNM stage I or II, $25.2 \%$ stage IIIA and $8.6 \%$ stage IIIB or IV (2.1\% unknown).

Chemotherapy used a single agent in $11.7 \%$ of the cases, two in $39.5 \%$, three in $17.8 \%$ and four or more in $31.0 \%$. Cisplatin was one of the drugs in $81.4 \%$ of the cases. The drugs used changed significantly over time: use of vindesine, cyclophosphamide and lomustine decreased significantly after 1986, while use of vinorelbine, ifosfamide and mitomycin-C increased significantly from 1986. The principal regimen during the first two periods was 
cisplatin-based chemotherapy with vindesine and/or cyclophosphamide and/or lomustine: $89.3 \%$ in $1982-85$, and $64.7 \%$ in 1986-89. The most common regimen in the last two periods was the combination of cisplatin and vinorelbine: $29.2 \%$ in $1990-93$, and $32.5 \%$ in 1994-97. Use of combined chemotherapy including cisplatin, ifosfamide and/or mitomycin-C began in 1990-93 and increased steeply over the last two periods: $8.4 \%$ in $1990-93$, and $19.2 \%$ in 1994-97. Monotherapy with vinorelbine began in 198689 , when it constituted $4.4 \%$ of the chemotherapy regimens, vs $15.0 \%$ in $1994-97$.

\section{Simple regressive analysis of relative survival}

Overall survival did not change significantly during the study period $(P=0.861)$. Median survival time was 10.3 months during the first period and 10.2 months during the last. For resectable disease, however, improvement of survival over time was on the borderline of statistical significance $(P=0.066)$ : MST in this group increased from 21.1 months in $1982-85$ to 35.8 months in 1990-93 and decreased slightly thereafter to 33.0 months in 1994-97. No differences from the first study period to the last were observed for locally advanced or metastatic disease $(P=0.273 ; P=0.160)$, with MST 8.5 and 9.7 months, respectively, in locally advanced disease, and 4.6 and 4.4 months in metastatic disease.

Overall, the 1-, 2- and 5-year survival probabilities were, respectively, $45.9,29.4$ and $15.7 \%$. For patients with resectable disease they were $71.3,53.9$ and $32.6 \%$, and $79.2,64.2$ and $41.1 \%$ for those whose tumours were resected. The 1- and 2-year survival probabilities for all patients with locally advanced disease were 38.2 and $15.6 \%$, for those treated by radiotherapy alone, 32.7 and $19.0 \%$, and for those receiving radiotherapy and chemotherapy, 49.3 and $17.6 \%$. These survival probabilities for all patients with metastatic disease were 16.8 and $5.2 \%$, and for those treated with chemotherapy alone, 24.1 and $5.9 \%$.

In all, 129 patients $(7.5 \%)$ died within a month of diagnosis: 91 $(70.5 \%)$ of them received no specific treatment.

Age $\left(P<10^{-5}\right)$, disease extent $\left(P<10^{-5}\right)$, histological subtype $\left(P<10^{-5}\right)$, and treatment $\left(P<10^{-5}\right)$ all had a significant influence on survival. Sex $(P=0.840)$ and inclusion in a clinical trial $(P=0.775)$ did not.

\section{Multiple regressive analysis of relative survival}

The multiple regressive analysis considered age, sex, disease extent, histological subtype, period and treatment in a forward stepwise procedure.

We first included only the pretherapeutic patients' and disease's characteristics. Age over 70 years, advanced disease and mixed subtype were less favourable prognostic factors, and the adenocarcinoma and bronchioloalveolar carcinoma histological subtypes more favourable (Table 4).

Then we included, separately for each stage (Tables $5,6,7$ ), characteristics of the patients, disease and treatment (because treatment depends strongly on stage). We excluded patients with bilateral disease or undetermined stage. We also excluded treatments administered to fewer than 20 patients, because there was not enough information to allow us to estimate the corresponding coefficient in the model (Table 3).

Age had no prognostic value in the models including treatment variables. Histology was a prognostic factor only in metastatic disease (Table 7): survival rate was higher for those with adenocarcinoma than with squamous-cell carcinoma. In resectable disease, survival was longer among patients undergoing only surgery or surgery and chemotherapy (Table 5). In locally advanced disease, the longest survival was observed with radiotherapy plus chemotherapy (Table 6).

In metastastic disease, patients treated with chemotherapy including new agents or classical agent with platin had a higher
Table 4 Multiple regressive survival analysis for pretherapeutic characteristics

\begin{tabular}{|c|c|c|c|}
\hline Variables & Hazard ratio & $\mathbf{C l}$ & $P$ \\
\hline Sex & & & 0.47526 \\
\hline Male & 1 & & \\
\hline Female & 0.938 & $0.786 ; 1.120$ & \\
\hline Age (years) & & & 0.00005 \\
\hline$\leqslant 55$ & 1 & & \\
\hline $56-70$ & 1.047 & $0.914 ; 1.199$ & \\
\hline$>70$ & 1.376 & $1.177 ; 1.610$ & \\
\hline Histology & & & 0.00243 \\
\hline Squamous-cell & 1 & & \\
\hline Adenocarcinoma & 0.844 & 0.733; 0.97। & \\
\hline Bronchioloalveolar & 0.645 & $0.469 ; 0.886$ & \\
\hline Large-cell & 0.972 & $0.807 ; 1.171$ & \\
\hline Mixed & 1.758 & $1.022 ; 3.026$ & \\
\hline Disease extent & & & $<10^{-5}$ \\
\hline Resectable disease & I & & \\
\hline Locally advanced disease & 2.785 & $2.386 ; 3.251$ & \\
\hline Metastatic disease & 5.410 & $4.706 ; 6.219$ & \\
\hline Bilateral disease & 2.079 & $1.451 ; 2.978$ & \\
\hline Undertermined & 6.125 & $4.559 ; 8.229$ & \\
\hline Period & & & 0.46030 \\
\hline $1982-85$ & 1 & & \\
\hline $1986-89$ & 0.978 & $0.831 ; 1.152$ & \\
\hline $1990-93$ & 0.897 & $0.764 ; 1.054$ & \\
\hline $1994-97$ & 0.911 & $0.777: 1.068$ & \\
\hline
\end{tabular}

Table 5 Multiple regressive survival analysis for pretherapeutic and therapeutic variables in resectable disease

\begin{tabular}{|c|c|c|c|}
\hline Variables & Hazard ratio & IC & $P$ \\
\hline Sex & & & 0.21884 \\
\hline Male & 1 & & \\
\hline Female & 0.811 & $0.575 ; 1.142$ & \\
\hline Age (years) & & & 0.79369 \\
\hline$\leqslant 55$ & 1 & & \\
\hline $56-70$ & 1.025 & $0.802 ; 1.310$ & \\
\hline$>70$ & 0.936 & $0.679 ; 1.291$ & \\
\hline Histology & & & 0.88776 \\
\hline Squamous-cell & 1 & & \\
\hline Adenocarcinoma & 0.952 & $0.741 ; 1.221$ & \\
\hline Bronchioloalveolar & 0.913 & $0.576 ; 1.449$ & \\
\hline Large-cell & 1.069 & $0.7|8 ; 1.59|$ & \\
\hline Mixed & 1.481 & $0.608 ; 3.605$ & \\
\hline Treatments & & & $<10^{-5}$ \\
\hline Surgery alone & 1 & & \\
\hline Surgery+radio+chemotherapy & 1.656 & $1.055 ; 2.598$ & \\
\hline Chemo+radiotherapy & 3.761 & $2.336 ; 6.055$ & \\
\hline Surgery+chemotherapy & 0.888 & $0.497 ; 1.589$ & \\
\hline Surgery+radiotherapy & 1.944 & $1.492 ; 2.533$ & \\
\hline Radiotherapy alone & 3.534 & $2.640 ; 4.730$ & \\
\hline Supportive care alone & 5.353 & $3.637 ; 7.878$ & \\
\hline Period & & & 0.49530 \\
\hline $1982-85$ & 1 & & \\
\hline $1986-89$ & 1.013 & $0.778 ; 1.319$ & \\
\hline $1990-93$ & 0.837 & $0.635 ; 1.104$ & \\
\hline $1994-97$ & 0.949 & $0.724 ; 1.245$ & \\
\hline
\end{tabular}


Table 6 Multiple regressive survival analysis for pretherapeutic and therapeutic variables in locally advanced disease

\begin{tabular}{|c|c|c|c|}
\hline Variables & Hazard ratio & IC & $P$ \\
\hline Sex & & & 0.07994 \\
\hline Male & I & & \\
\hline Female & 1.538 & $0.972 ; 2.435$ & \\
\hline Age (years) & & & 0.60239 \\
\hline$\leqslant 55$ & । & & \\
\hline $56-70$ & 1.155 & $0.845 ; 1.579$ & \\
\hline$>70$ & 1.035 & $0.705 ; 1.519$ & \\
\hline Histology & & & 0.68538 \\
\hline Squamous-cell & | & & \\
\hline Adenocarcinoma & 1.147 & $0.802 ; 1.641$ & \\
\hline Large-cell & 0.975 & $0.635 ; 1.498$ & \\
\hline Mixed & 2.301 & $0.516 ; 10.267$ & \\
\hline Treatment & & & 0.00009 \\
\hline Chemo+radiotherapy & 1 & & \\
\hline Chemotherapy alone & 2.227 & I.448; 3.426 & \\
\hline Radiotherapy alone & 1.457 & $1.034 ; 2.053$ & \\
\hline Supportive care alone & 3.560 & $2.238 ; 5.665$ & \\
\hline Period & & & 0.59819 \\
\hline $1982-85$ & 1 & & \\
\hline $1986-89$ & 0.796 & $0.536 ; 1.183$ & \\
\hline $1990-93$ & 0.974 & $0.678 ; 1.399$ & \\
\hline $1994-97$ & 1.002 & $0.675 ; 1.487$ & \\
\hline
\end{tabular}

survival rate than patients treated by classical agent without platin or palliative care only (Table 7 ).

\section{DISCUSSION}

The sex-ratio decreased significantly over time from 10.6/1 in $1982-85$ to $6.7 / 1$ in 1994-1997. Analysis of all French registries over this period shows the same trend in sex-ratio for lung cancer: $10.1 / 1$ in 1980 and 6.0/1 in 1995 (Remontet et al, 2003). This trend illustrates the progressive burden of this disease in French women, related to their increasing regular use of tobacco since the end of the Sixties (Hill, 1998), more than two decades after women began smoking regularly in the US (US Public Health Service, 1980). The sex-ratio there is about $2 / 1$ now, and lung cancer is the leading cause of cancer death in women (US Public Health Service, 2001).

The median age at diagnosis among the 1738 patients included in the sample was 63 years, lower than in other European population-based studies, which have found a median age of roughly 70 years (Gregor et al, 2001; Koyi et al, 2002; Mahmud et al, 2003). These series, however, unlike our study, included lung cancer patients $(14-26 \%)$ not histologically confirmed, the confirmation rates declining with age (Koyi et al, 2002; Mahmud et al, 2003).

The distribution of disease extent also changed significantly during the study period. The percentage of patients with metastatic disease increased, as did the number of metastatic sites and the imaging procedures. This suggests that at least part of the increased frequency of metastatic disease may be due to stage migration, a well-known phenomenon (Feinstein et al, 1985). Cases classified as resectable accounted for $45.2 \%$ of the entire sample, and locally advanced stage for only $18.0 \%$. This high percentage of resectable disease probably has two primary causes, the first being the absence of thorax CT scans during the early periods. Second, mediastinoscopy is not routine in France (Depierre et al, 2002), so that patients with stage IIIA disease often undergo surgery.
Table 7 Multiple regressive survival analysis for pretherapeutic and therapeutic variables in metastatic disease

\begin{tabular}{|c|c|c|c|}
\hline Variables & Hazard ratio & IC & $P$ \\
\hline Sex & & & 0.38535 \\
\hline Male & 1 & & \\
\hline Female & 0.895 & $0.696 ; 1.152$ & \\
\hline Age (years) & & & 0.63040 \\
\hline$\leqslant 55$ & 1 & & \\
\hline $56-70$ & 0.908 & $0.725 ; 1.136$ & \\
\hline$>70$ & 0.979 & $0.745 ; 1.287$ & \\
\hline Histology & & & 0.01699 \\
\hline Squamous-cell & 1 & & \\
\hline Adenocarcinoma & 0.751 & $0.607 ; 0.929$ & \\
\hline Bronchioloalveolar & 0.586 & $0.351 ; 0.978$ & \\
\hline Large-cell & 1.023 & $0.788 ; 1.330$ & \\
\hline Mixed & $1.36 \mid$ & $0.553 ; 3.347$ & \\
\hline Treatments & & & $<10^{-5}$ \\
\hline $\begin{array}{l}\text { Chemotherapy alone with classical } \\
\text { agents and platin }\end{array}$ & I & & \\
\hline $\begin{array}{l}\text { Chemotherapy alone with recent } \\
\text { agents and platin }\end{array}$ & 0.749 & $0.547 ; 1.026$ & \\
\hline $\begin{array}{l}\text { Chemotherapy alone with recent } \\
\text { agents w/o platin }\end{array}$ & 1.069 & $0.722 ; 1.583$ & \\
\hline $\begin{array}{l}\text { Chemotherapy alone with classical } \\
\text { agents w/o platin }\end{array}$ & 2.010 & I.142; 3.540 & \\
\hline Chemo+radiotherapy & 0.727 & $0.501 ; 1.055$ & \\
\hline Radiotherapy alone & 1.359 & $0.982 ; 1.881$ & \\
\hline Supportive care alone & 2.316 & $1.749 ; 3.067$ & \\
\hline Period & & & 0.23791 \\
\hline $1982-85$ & I & & \\
\hline $1986-89$ & 0.981 & $0.732 ; 1.315$ & \\
\hline $1990-93$ & 1.088 & $0.821 ; 1.442$ & \\
\hline $1994-97$ & 1.272 & $0.949 ; 1.704$ & \\
\hline
\end{tabular}

Disease management changed over the study period, especially for the locally advanced and metastatic stages. Surgery alone remained the primary treatment for resectable disease throughout the period. Combined treatments, such as surgery plus radiotherapy plus chemotherapy or surgery plus chemotherapy, remained relatively infrequent, as seen in a 10-year survey in the US (Fry et al, 1999). The meta-analysis published in 1995 (NSCLCCG, 1995) did not provide clear evidence that chemotherapy, especially adjuvant chemotherapy, is effective in prolonging survival in these cases. Similarly, only two small randomised studies of neoadjuvant chemotherapy were published during the study period (Rosell et al, 1994). Accordingly, no significant modification in the use of chemotherapy for resectable disease was to be expected.

Use of radiotherapy alone in resectable disease decreased during the study period, while surgery was increasingly used. This observation is consistent with other reports (Janssen-Heijnen and Coebergh, 2003). This trend may be related to advances in operative technique and perioperative care that have prompted greater recourse to surgery (Bolliger and Perruchoud, 1998). Postoperative radiotherapy in resected stage IIIAN2 disease is widely used in France as elsewhere (Emami and Perez, 1992) and did not change significantly during the study period.

The PORT meta-analysis confirmed the detrimental effect of postoperative radiotherapy in resected stage I and II disease and found its role in completely resected stage IIIA disease still unclear: an improvement of the local control but no effect on survival (PORT Meta-analysis Trialists Group, 1998).

The use of platinum-based chemotherapy in conjunction with radiotherapy in patients with locally advanced unresectable 
NSCLC has become standard in France since the publication by Le Chevalier et al (1991). In our study, chemotherapy plus radiotherapy in locally advanced disease increased significantly during the study period, from 21.2 to $59.1 \%$. Inversely the use of radiotherapy alone decreased significantly, from 53.8 to $12.9 \%$. Similar trends in the treatment of locally advanced NSCLC have been reported for the US (Fry et al, 1999).

The use of chemotherapy for metastatic disease also increased over time. Practices in our study were consistent with findings in the meta-analysis (NSCLCCG, 1995) with cisplatin-based chemotherapy being the most common first-line approach. Many studies reported that cisplatin-based combinations were associated with better response rates and sometimes better survival than monotherapy, and these combinations eventually became standard practice (Depierre et al, 1994; Le Chevalier et al, 1994). In our study, $11.7 \%$ of the patients treated by chemotherapy received one drug, $39.5 \%$ two, $17.8 \%$ three, and $31.0 \%$ four or more.

We did not see any improvement in overall survival between 1982 and 1997. In the retrospective analysis of patients with extensive NSCLC treated in the clinical trials of the SWOG between 1974 and 1988, an improved survival was observed for those treated with cisplatin-based chemotherapy (Albain et al, 1991), a treatment introduced during the 1980s. The European retrospective analysis of patients with advanced NSCLC enrolled in clinical trials between 1980 and 1991 observed no improvement in survival according to period of diagnosis (Paesmans et al, 1995). A study of 22 years of phase III trials for patients with advanced NSCLC (Breathnach et al, 2001) showed modest progress in survival for these patients: MST increased from 5.2 months in the early period (1973 to 1983) to 5.8 months in the later one (1984 to 1994).

Nevertheless, this improved survival from one clinical trial to another cannot be definitely attributed to improvement of therapies. The increasingly restrictive inclusion criteria may be a factor in the improved outcome of study subjects. These selection biases limit, of course, the generalisability of the results obtained in clinical trials to the real-life population of patients. Comorbidities, often linked to tobacco use, may prevent patients in the general population from receiving the optimal treatment (JanssenHeijnen et al, 1998). The Will Rogers phenomenon (Feinstein et al, 1985) may also account for at least some of the improved survival observed in consecutive trials.

Lead time bias is another possible explanation for the improvements in survival observed in clinical trials. This bias is the only one of those mentioned here that is also possible in population-based studies, because the general population may also become more aware of lung cancer symptoms over time and consult earlier. Population-based studies are therefore of the utmost importance in assessing treatment efficiency and providing insight into public health policies.

Few population-based analyses of survival in patients with NSCLC have been published. MST of all patients with NSCLC in the SEER-database increased from 9.1 months in 1974-75 to 10 months in 1993-94 and the 3- and 5-year survival rates increased, respectively, by 2 and 4 points (Breathnach et al, 2001). A large hospital-based cancer registry showed no improvement in survival from 1985 through 1995 (Fry et al, 1999).

Elderly patients are excluded from clinical trials frequently and receive optimal treatment less often than younger patients (Earle et al, 2002). Their frequent comorbidities and frailty often preclude administration of the standard treatment (Janssen-Heijnen et al, 1998). But advanced age in itself does not contraindicate aggressive treatment (Deppermann, 2001; Langer et al, 2002). Age was not a prognostic factor in our study when we took into account the specific treatment administered. In various cancers, such as NSCLC (Foucher et al, 1993), studies using relative survival often dismiss age as a significant prognostic factor.

Performance status is probably the best single prognostic factor with stage in NSCLC (Albain et al, 1991). Unfortunately, in this population-based study there were too many missing values. It is not unlikely that more patients with bad PS were histologically diagnosed with lung cancer during the latter end rather than at the beginning of the study period as was demonstrated by UK cancer registries (Cartman et al, 2002). This could at least partially explain the absence of detection of an overall improvement in survival.

We did not observe any protective effect linked to female sex in our study. Several studies report better prognosis for women with NSCLC cancer than for men (Albain et al, 1991; Paesmans et al, 1995; Radzikowska et al, 2002), although not consistently (Keller et al, 2002).

Adenocarcinoma was associated with longer survival in the metastatic stage than squamous-cell carcinoma. The prognostic role of histological type remains controversial (Sculier et al, 1994; Charloux et al, 1997; Fry et al, 1999). Changes in pathology classifications over the years may account in part for these discrepancies.

Disease stage at diagnosis is the most important prognostic factor. Five-year relative survival for patients with resectable disease was $32.6 \%$, regardless of the treatment. It was $41.1 \%$ for those who underwent surgery (alone or combined with other treatments), which can be compared to the 5-year crude survival in surgical series: $40.4 \%$ for the surgery arm, with or without postoperative radiotherapy in the IALT trial (The IALT Collaborative Group, 2004), and $43 \%$ in the surgery alone arm of the post-operative radiation therapy trial (Dautzenberg et al, 1999).

In our study, among patients with resectable disease, survival was shorter for those who could not undergo surgery and for those who had surgery and radiotherapy. This combined therapy, however, reflects their advanced pTNM stage: $64.6 \%$ of them had post-operative stage IIIA and $11.5 \%$ stage IIIB.

In locally advanced disease, the 1-year survival rate was $32.7 \%$ for patients treated by radiotherapy alone and $49.3 \%$ for those treated with radiotherapy plus chemotherapy. These results are similar to those previously reported in a clinical trial (Le Chevalier et al, 1991).

In metastatic disease, the 1-year survival rate was $16.8 \%$ for the overall sample, it was $24.1 \%$ for the patients who received only chemotherapy, a rate very close to that reported in the chemotherapy arms of clinical trials comparing chemotherapy to the best supportive care (NSCLCCG, 1995). Those patients with metastatic disease who were treated with platin-based chemotherapy had the best survival and in this group we observed a trend towards better results with the new agents combined with platin. The recently published phase III trials that included hundreds of patients with advanced NSCLC, did not demonstrate the superiority of any one combination of a platinum salt with a new agent over any other (Kelly et al, 2001; Schiller et al, 2002).

Overall, $16.7 \%$ of our patients received only palliative care. This percentage is to be compared to the $14 \%$ to $19 \%$ in the NCDB series (Fry et al, 1999), 43.2\% in the Scottish population-based series (Gregor et al, 2001), and 39.8\% in the Irish (Mahmud et al, 2003). The higher percentages in the two latter studies may be partly explained by the inclusion of patients with unconfirmed lung cancer and probably too frail to undergo diagnostic procedures.

Despite changes in treatments in accordance with the state of the art, survival did not improve. Nevertheless, the survival rates observed in our series are very similar to those reported in recent phase III clinical trials that include highly selected patients.

Several authors argue that SCLC is a more chemoresponsive disease than NSCLC, so that improved survival is more likely to be observed in patients with the former disease (Breathnach et al, 2001; Janssen-Heijnen and Coebergh, 2003). A previous study observed a significant improvement in survival in patients diagnosed with SCLC in the Bas-Rhin between 1981-83 and 1993-94 (Lebitasy et al, 2001).

These findings may also reflect the continuing pre-eminence of surgery in curing NSCLC. The benefits of chemotherapy in more advanced disease still appear too small to be translated into 
improved overall survival in an entire patient population, some being unable to receive chemotherapy. Thus, the impact of these newer treatments on survival will become apparent when a much greater proportion of patients will be treated with the appropriate treatment, and perhaps the final cohort was too early in the evolution of NSCLC management to outbalance the above factors.

\section{ACKNOWLEDGEMENTS}

This work has been financed through the Strasbourg Hospital Clinical Research Project. We are also indebted to Drs E Achille,
Y Anselm, P Bareiss, P Baur, JP Bergerat, M Berthel, B Brunet, P Charles, A Ducolone, P Dufour, D Feuerstoss, A Harrosch, N Hutt, A Jaeger, P Kehr, G Kleiber, JJ Kolher, C Meyer, Moniatte, A Moritz, L Nguyen Ngoc, E Noel, S Reibel, R Revelant, JC Ruch, P Sauder, F Schaeffer, JL Schlienger, S Schraub, D Storck, P Vautravers, JP Wagner, E Weitzenblum, J Wertenschlag, JM Wihlm, A Wilk, B Woerly (Strasbourg), Kistler (Benfeld), P Bruant, J Cherfan, MC Dickele, F Matzinger, M Morel, B Petit, R Seibert, B Willemin (Haguenau), JJ Class, JM Nuss (Ingwiller), A Jory (Saales), F Brolly, F Loth, B Orion (Saverne), D Becker (Schirmeck), Y Krummel, J North, JF Sagez, S Taieb (Sélestat) and A Michel (Wissembourg), who allowed us to review the patients'medical charts.

\section{REFERENCES}

Albain KS, Crowley JJ, LeBlanc M, Livingston RB (1991) Survival determinants in extensive-stage non-small-cell lung cancer: the Southwest Oncology Group Experience. J Clin Oncol 9: 1618-1626

Bolliger CT, Perruchoud AP (1998) Functional evaluation of the lung resection candidate. Eur Respir J 11: 198-212

Breathnach OS, Freidlin B, Conley B, Green MR, Johnson DH, Gandara DR, O'Connell M, Shepherd FA, Johnson BE (2001) Twenty-two years of phase III trials for patients with advanced non-small-cell lung cancer: sobering results. J Clin Oncol 19: $1734-1742$

Cartman ML, Hatfield AC, Muers MF, Peake MD, Haward RA, Forman D (2002) Lung cancer: district active treatment rates affect survival. J Epidemiol Commun Health 56: 424-429

Charloux A, Hedelin G, Dietemann A, Ifoundza T, Roeslin N, Pauli G, Quoix E (1997) Prognostic value of histology in patients with non-small cell lung cancer. Lung Cancer 17: $123-134$

Dautzenberg B, Arriagada R, Chammard AB, Jarema A, Mezzeti M, Mattson K, Lagrange JL, Le Pechoux C, Lebeau B, Chastang C (1999) A controlled study of postoperative radiotherapy for patients with completely resected nonsmall cell lung carcinoma. Cancer 86: 265-273

Depierre A, Chastang C, Quoix E, Lebeau B, Blanchon F, Paillot N, Lemarie E, Milleron B, Moro D, Clavier J, Herman D, Tuchais E, Jacoulet P, Brechot JM, Cordier JF, Solal-Celigny P, Badri N, Besenval M (1994) Vinorelbine versus vinorelbine plus cisplatin in advanced non-small cell lung cancer: a randomized trial. Ann Oncol 5: 37-42

Depierre A, Milleron B, Moro-Sibilot D, Chevret S, Quoix E, Lebeau B, Braun D, Breton JL, Lemarie E, Gouva S, Paillot N, Brechot JM, Janicot H, Lebas FX, Terrioux P, Clavier J, Foucher P, Monchatre M, Coetmeur D, Level MC, Leclerc P, Blanchon F, Rodier JM, Thiberville L, Villeneuve A, Westeel V, Chastang C (2002) Preoperative chemotherapy followed by surgery compared with primary surgery in resectable stage I (except T1N0), II, and IIIa non-small-cell lung cancer. J Clin Oncol 20: 247-253

Deppermann KM (2001) Influence of age and comorbidities on the chemotherapeutic management of lung cancer. Lung Cancer 33: S115-S120

Earle CC, Neumann PJ, Gelber RD, Weinstein MC, Weeks JC (2002) Impact of referral patterns on the use of chemotherapy for lung cancer. J Clin Oncol 20: $1786-1792$

Emami B, Perez C (1992) Lung. In Princile and Practice of Radiation Oncology 2nd edn, Perez CA, Brady LW (eds) pp 806-836. Philidelphia: JB Lippincott

Estève J, Benhamou E, Croasdale M, Raymond L (1990) Relative survival and the estimation of net survival: elements for further discussion. Stat Med 9: $529-538$

Feinstein AR, Sosin DM, Wells CK (1985) The Will Rogers pnenomenon. Stage migration and new diagnostic techniques as a source of misleading statistics for survival in cancer. N Engl J Med 312: 1604-1608

Ferlay J, Bray F, Pisani P, Parkin DM (2001) GLOBOCAN 2000: Cancer Incidence, Mortality and Prevalence Worldwide, Version 1.0.. IARC CancerBase No.5, Lyon: IARC Press., Limited version available from: http://www-dep.iarc.fr/globocan/globocan.htm

Foucher P, Coudert B, Arveux P, Boutron MC, Kisterman JP, Bernard A, Faivre J, Jeannin L (1993) Age and prognosis of non-small cell lung cancer. Usefulness of a relative survival model. Eur J Cancer 29A: $1809-1813$
Fry WA, Phillips JL, Menck HR (1999) Ten-Year survey of lung cancer treatment and survival in hospitals in the United States: a national cancer data base report. Cancer 86: $1867-1876$

Gregor A, Thomson CS, Brewster DH, Stroner PL, Davidson J, Fergusson RJ, Milroy R (2001) Management and survival of patients with lung cancer in Scotland diagnosed in 1995: results of a national population based study. Thorax 56: $212-217$

Hédelin G (2003) Relsurv 2.5c: a programme for relative survival. Technical report of the department of epidemiology and public health, Faculty of Medecine, Louis Pasteur University, Strasbourg, France

Hill C (1998) Trends in tobacco smoking and consequences on health in France. Prev Med 27: 514-519

Hill C, Doyon F (2004) Frequency of cancer in France: 2004 update. Bull Cancer 91: $9-14$

INSEE (Institut national de la statistique et des études économiques) (1982, 1990, 1999) Recensements de la population. http://recensement.insee.fr

Janssen-Heijnen ML, Coebergh JW (2003) The changing epidemiology of lung cancer in Europe. Lung Cancer 41: 245-258

Janssen-Heijnen ML, Schipper RM, Razenberg PP, Crommelin MA, Coebergh JW (1998) Prevalence of co-morbidity in lung cancer patients and its relationship with treatment: a population-based study. Lung Cancer 21: $105-113$

Jung SH, Hui S (2002) Sample size calculation for rank tests comparing K survival distributions. Lifetime Data Anal 8: 361-373

Keller SM, Vangel MG, Adak S, Wagner H, Schiller JH, Herskovic A, Komaki R, Perry MC, Marks RS, Livingston RB, Johnson DH (2002) The influence of gender on survival and tumor recurrence following adjuvant therapy of completely resected stages II and IIIA non-small cell lung cancer. Lung Cancer 37: 303 - 309

Kelly K, Crowley J, Jr BPA, Presant CA, Grevstad PK, Moinpour CM, Ramsey SD, Wozniak AJ, Weiss GR, Moore DF, Israel VK, Livingston RB, Gandara DR (2001) Randomized phase III trial of paclitaxel plus carboplatin versus vinorelbine plus cisplatin in the treatment of patients with advanced non-small-cell lung cancer: a Southwest Oncology Group trial. J Clin Oncol 19: 3210-3218

Koyi H, Hillerdal G, Brandén E (2002) A prospective study of a total material of lung cancer from a county in Sweden 1997-1999: gender, symptoms, type, stage, and smoking habits. Lung Cancer 36: 9-14

Langer CJ, Manola J, Bernardo P, Kugler JW, Bonomi P, Cella D, Johnson DH (2002) Cisplatin-based therapy for elderly patients with advanced non-small-cell lung cancer: implications of Eastern Cooperative Oncology Group 5592, a randomized trial. J Natl Cancer Inst 94: $173-181$

Le Chevalier T, Arriagada R, Quoix E, Ruffie P, Martin M, Tarayre M, Lacombe-Terrier MJ, Douillard JY, Laplanche A (1991) Radiotherapy alone versus combined chemotherapy and radiotherapy in nonresectable non-small-cell lung cancer: first analysis of a randomized trial in 353 patients. J Natl Cancer Inst 83: 417-423

Le Chevalier T, Pujol JL, Douillard JY, Alberola V, Monnier A, Riviere A, Lianes P, Chomy P, Cigolari S, Besson F, Berthaud P, Brisgand D (1994) A three-arm trial of vinorelbine (Navelbine) plus cisplatin, vindesine plus cisplatin, and single-agent vinorelbine in the treatment of non-small cell lung cancer: an expanded analysis. Semin Oncol 21: 28-33, discussion $33-34$. 
Trends in management of non-small-cell lung cancer patients

J Foeglé et al
Lebitasy MP, Hédelin G, Purohit A, Moreau L, Klinzig F, Quoix E (2001) Progress in the management and outcome of small-cell lung cancer in a French region from 1981 to 1994. Br J Cancer 85: 808-815

Mahmud SM, Reilly M, Comber H (2003) Patterns of initial management of lung cancer in the Republic of Ireland: a population-based observational study. Lung Cancer 41: 57-64

Mountain CF (1997) Revisions in the International System for Staging Lung Cancer. Chest 111: 1710-1717

Non-small Cell Lung Cancer Collaborative Group (NSCLCCG) (1995) Chemotherapy in non-small cell lung cancer: a meta-analysis using updated data on individual patients from 52 randomised clinical trials. BMJ 311: 899-909

Northern and Yorkshire Cancer Registry and Information Key Sites Study. Cancer treatment policies and their effects on survival: lung cancer. Report 2 of the Key Sites Study. Northern and Yorkshire Cancer Registry and Information Service, Leeds, UK, 1999

Paesmans M, Sculier J, Libert P, Bureau G, Dabouis G, Thiriaux J, Michel J, Van Cutsem O, Sergysels R, Mommen P, Klastersky J (1995) Prognostic factors for survival in advanced non-small-cell lung cancer: univariate and multivariate analyses including recursive partitioning and amalgamation algorithms in 1,052 patients. J Clin Oncol 13: $1221-1230$

PORT Meta-analysis Trialists Group (1998) Postoperative radiotherapy in non-small-cell lung cancer: systematic review and meta-analysis of individual patient data from nine randomised controlled trials. Lancet 352: $257-263$

Radzikowska E, Glaz P, Roszkowski K (2002) Lung cancer in women: age, smoking, histology, performance status, stage, initial treatment and survival. Population-based study of 20561 cases. Ann Oncol 13: $1087-1093$

Remontet L, Buemi A, Velten M, Jougha E, Estève J (2003) Evolution de l'incidence et de la mortalité par cancer en France de 1978 à 2000 pp. 79-85. Institut de Veille Sanitaire: Paris
Rosell R, Gomez-Codina J, Camps C, Maestre J, Padille J, Canto A, Mate JL Li S, Roig J, Olazabal A, Canela M, Ariza A, Skacel Z, Morera-Prat J, Abad A (1994) A randomized trial comparing preoperative chemotherapy plus surgery with surgery alone in patients with non-small-cell lung cancer. $N$ Engl J Med 330: $153-158$

Roth JA, Fossella F, Komaki R, Ryan MB, Putnam JBJ, Lee JS, Dhingra H, De Caro L, Chasen M, McGavran M, Atkinson EN, Ki Hong W (1994) A randomized trial comparing preoperative chemotherapy and surgery with surgery alone in resectable stage IIIA non-small cell lung cancer. J Natl Cancer Inst 86: 673-680

Schiller JH, Harrington D, Belani CP, Langer C, Sandler A, Krook J, Zhu J, Johnson DH (2002) Comparison of four chemotherapy regimens for advanced non-small-cell lung cancer. $N$ Engl J Med 346: 92 - 98

Sculier JP, Paesmans M, Libert P, Bureau G, Dabouis G, Thiriaux J, Michel J, Van Cutsem O, Schmerber J, Giner V, Berchier MC, Sergysels R, Mommen P, Klastersky J (1994) Long-term survival after chemotherapy containing platinum derivatives in patients with advanced unresectable non-small cell lung cancer. Eur J Cancer 30A: 1342-1347

Souquet PJ, Chauvin F, Boissel JP, Cellerino R, Cormier Y, Ganz PA, Kaasa S, Pater JL, Quoix E, Rapp E, Tumarello D, Williams J, Woods BL, Bernard JP (1993) Polychemotherapy in advanced non small cell lung cancer: a meta-analysis. Lancet 342: 19-21

The International Adjuvant Lung Cancer Trial (IALT) Collaborative Group (2004) Cisplatin-based adjuvant chemotherapy in patients with completely resected non-small-cell lung cancer. N Engl J Med 350: 351-360

United States Public Health Service (1980) The health consequences of smoking for women. Report of the Surgeon General. United States Department of Health and Human Services, Office of Smoking and Health. US Government Printing Office, Washington DC

United States Public Health Service (2001) Women and smoking - a report of the Surgeon General. US Departement of health and human services, CDC, Office of Smoking and Health 